\title{
Towards a sustainable mining habitat in South Africa
}

\author{
J. E. Drewes \& M. van Aswegen \\ Department Urban and Regional Planning, Northwest University, \\ South Africa
}

\begin{abstract}
Mining is South Africa's largest industry in the primary economic sector (2006) and contributed R94,3 billion (US\$14,8 billion) or 7\% to the country's Gross Value Added. During this time, the mining industry employed 2,6\% of South Africa's economically active population, which implicates 443300 employees and households. The isolated location of most of these natural resources has led to a spatially dispersed pattern of mining activities and settlements. Traditionally, mining companies in South Africa provided housing facilities for their employees in unsustainable mining settlements, which usually materialise into ghost-towns when operations close down. Employees are mostly accommodated in company-owned (operation based) housing. Due to the historically patriarchal approach to the provision of housing, a lack of knowledge regarding tenure, investment and financial issues ensued. An emphasis shift has since occurred in some guiding policies in the mining sector (e.g. the Mining Charter) and various spatial planning policies (e.g. the National Spatial Development Perspective) in South Africa. These policies propose a more sustainable approach to settlements in general, but lack specific guidelines relevant to the abovementioned planning practice. This paper will exemplify how the emphasis on creating economically and socially viable communities can potentially realise the global vision of sustainable human settlements (refer to United Nations, Habitat Agenda). It will be argued that emphasis should be on the development of sustainable towns and the encouragement of homeownership. The main objectives of this paper are to provide guidance to mining companies to facilitate housing in sustainable settlements.
\end{abstract}

Keywords: sustainable housing, mining settlements, company town, housing policy, UN Habitat, South Africa. 


\section{Background}

Traditionally, mining companies provided housing facilities for their employees on mine-owned land within close proximity to the mining operations. The mining sector is the only sector in South Africa (except for government initiatives in terms of low-cost housing), which still provides housing for employees on such a large scale and on a national level.

Housing is regarded as an urban function within a broader spatial system of urban settlements. The housing function within a city is unique and depends on a combination of numerous factors, including local and national influences. Typically, the housing function will be influenced by a city's site, topography, transport system, income level, social heterogeneity and economic base.

At least five broad definitions of housing appear in relevant literature. Housing can either refer to a physical facility (providing shelter); an economic commodity (investment); a social good (element of social fabric); a package of services (including social services); or lastly as a sector of the economy (fixed capital stock) (Bourne [1]). Housing, in this context, provides shelter to mining employees and acts as an investment to both the mining company and the employee. Housing cannot be seen in isolation, but should be evaluated as an integral part of urban morphology, including social services and amenities. Therefore, housing should claim an important role in both the milieu of the mining company, the mine employee and the larger system of urban settlements as envisaged by the Habitat Agenda (UN [2]).

\section{The spatial disposition of mine housing}

The isolated location of most primary resources extracted by the mining sector has led to a spatially dispersed pattern of mining activities. The acquisition of labour is seen as a big challenge in these far-off locations since most mining activities make use of intensive labour. Naturally, housing became a problematic issue within the mining sector. Mines throughout South Africa were faced with the problem of minimising capital costs, which proved impossible to do. This in turn led to the realisation that if capital cost can't be cut, labour cost should be reduced (Demissie [3]). The only workable alternative at that time for the more expensive white labour was to make use of the cheap and abundant supply of African labour. This was achieved by paying wages only equivalent to the worker's own personal needs, not those of his family as well, and housing the mine workers in hostels or compounds on mine property, where the workers could be close to work and kept under a close watch. Rex [4] described these hostels (see Figure 1) as "a kind of bachelor barracks to which workers retire when off-shift to bunk beds in communal dormitories and receive their food in a specially provided communal kitchen".

Demissie [3] highlighted that the design of mine housing was intended to function in three different ways, i.e. (i) to separate the mine workers from the rest of the community; (ii) as a deterrent against uprising; and (iii) as a basis for fragmenting mine workers' solidarity. During the 1970's and 1980's changing 


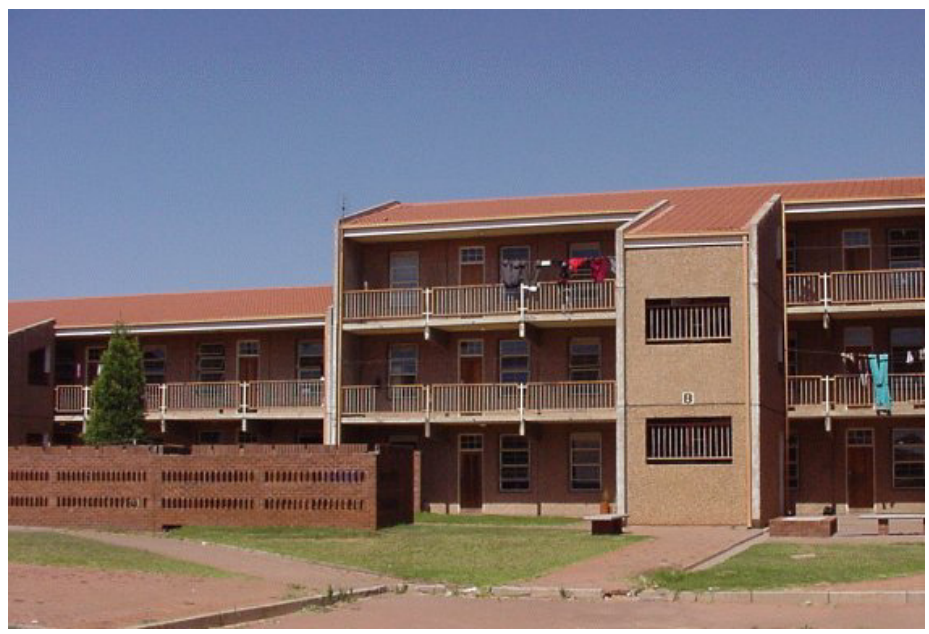

Figure 1: $\quad$ Typical mine hostel.

labour markets and political unrest created a labour crisis (Demissie [3]), which forced the mining industry to seek alternatives to migrant labour. The mining industry adopted a recruitment strategy through higher wages, rental housing and home ownership to attract workers from within South Africa. As part of the strategy to reduce the dependence on foreign workers, two complimentary schemes were pursued. Firstly, the industry began to build more rental housing for married African workers and secondly, accommodation provision was accelerated through the development of company towns on mine property, or company towns within nearby settlements. These housing schemes of the mine industry mainly attracted higher income category workers, including skilled and semi-skilled workers.

From an urban perspective, Africa's cities represent a variety of forms due to the different traditions and variety of cultures on the continent. O'Connor [5]) distinguishes between a number of housing types in the African cities which include private employer housing, which refers to housing provided for the employee by the employer. Private employer housing was regarded as a way to minimise the African population within the European cities. Even today, many private companies continue to provide housing for their employees, notable examples being the mining companies. O'Connor [5] is of opinion that "Paternalism remains in evidence when employees are given housing allowance rather than a suitably adjusted wage, but this does not mean that employees of large private companies are now increasingly part of the general housing markets". Due to this legacy many mining companies are in a position where they still provide company housing for their employees, and where employees expect this from the employer.

Crush and James [6] identified four models of housing delivery in which mines mainly experimented. Firstly the township model represents a model where mine owners prefer to see workers settled in owner-occupied houses in 
established or new townships close to mine properties. Secondly, the company town model, had its existence from mines that are distant from existing townships, the mines were forced to create their own townships on or close to mine property. The third model of self-help housing refers to a model in which the mining company institutes a wage adjustment with which employees can either buy company houses or make their own rental or home purchase agreements. The last model is that of urban labour and constitutes of mine companies mainly recruiting from urban areas, in this way the mines will be spared the expense of providing new accommodation. This approach was not as successful as hoped.

The abovementioned housing types are still the main form of provision for housing in mine areas and for mine workers, especially in the remote areas where most of the South African mines operate. The hostel concept is not as common but still exists on many of the South African mines, while the township model and the company town model is still found all over South Africa. This is in stark contrast to the vision and principles of internationally accepted policies [2].

From this section it is apparent that mining companies can no longer sustain the models of housing provision they instated at the mines, and are in critical need of an innovative approach to housing development.

\section{Housing policy directives}

At the time of the first democratic elections (1994) the newly elected government inherited a spatially deficient urban and housing structure with the complex task of trying to correct past mistakes of the previous regime. In this regard a number of national post-apartheid policies have been implemented. An apparent void exists for the development of policy and related guidelines specifically aimed at the mining sector in South Africa. Over the past decade, however, numerous attempts have been made to provide guidance to mining companies in this respect.

The mining sector is the only sector in South Africa (except for government initiatives in terms of low-cost housing), which still provides housing for employees on such a large scale and on a national level. Government policy requires detailed urban analysis from mining companies and the sustainable construction of housing in existing urban settlements. Such settlements should be equipped with the necessary infrastructure and social amenities, i.e. sufficient 'critical mass'. It is, therefore, only natural that the mining sector, although not a single entity as the government, contribute to the responsible settlement of their employees within structured and able environments such as surrounding existing settlements.

On an international level, housing policy is mainly guided and influenced by the Habitat Agenda (UN [2]). The Habitat Agenda (UN [2]) places great emphasis on the development of sustainable human settlements that should be planned developed and improved in a manner that takes full account of sustainable development principles and all their components. In this context, the following principles are highlighted: 
- Integrating urban planning and management in relation to housing, transport, employment opportunities, environmental conditions and community facilities;

- Improving access to work, goods, services and amenities;

- Promoting, where appropriate, the creation of a geographically balanced settlement structure; and

- Promoting the development of more balanced and sustainable human settlements by encouraging productive investments.

From an employee perspective in South Africa, the National Union of Mineworkers (NUM) [7] voiced its concern on the lack of proper housing policy and addresses a certain number of elements of existing housing policy. They argued that "giving the unique nature and historical background, both in terms of the migrant labour policies of the apartheid government and the racially-based provision of accommodation in the mines...special attention (be) given to the mines with respect to housing policy, hostel redevelopment and provision of family housing". The NUM calls for a range of measures (NUM [7]), including that the duties of employers regarding the accommodation of their workforce should be regulated. It is further proposed that state subsidies for both hostel upgrade and conversion should be made available to mines that can prove they need them. The government is urged to indicate the process and timeframe for the completion of a detailed policy on private sector hostels. Government should also oblige all employers to meet the minimum requirements for housing their workforce and their families. NUM indicated that the mining companies must be obliged to annually produce plans for the improvement of their employees' housing conditions, including budgets and timeframes, with short, medium and long-term objectives.

In accordance with the Mining Charter (DME [8]) the general development goal for mine employees is that of improved living standards. The Mining Charter states that in terms of housing and living conditions stakeholders should undertake to establish measures for improving the standard of housing including the upgrading of hostels, conversion of hostels to family units and the promotion of home ownership options for mine employees.

From the Government's viewpoint, the National Spatial Development Perspective (NSDP) (SA [9]) is regarded as a guiding document with regard to spatial development in South Africa. This document, however, only briefly touches on the subject of housing in the mining sector. In the NSDP (SA [9]) government called for mine companies to ensure empowerment of employees through home ownership; and to move away from providing housing at unsustainable locations on mine land. The NSDP (SA [9]) further encourages mining companies to ensure that housing development is promoted in sustainable towns near the mining operations and not as isolated villages on mine-owned land. This aim closely relates to the goals and principles of sustainable development of the Habitat Agenda (UN [2]) as discussed.

Another guiding policy was issued by the Department of Housing in the form of the White Paper on Housing (DOH [10]). Accordingly, "circular migration and dual households, hostel accommodation, the prevalence of single (often 
female headed) households, cultural and legal impediments to access for women housing, and traditional tenure systems" pose important constraints on housing policy in South Africa. The White Paper does not however provide for specific housing policy regarding mine housing, but did call for employers to "know the housing circumstances of their employees and to, within their means, provide advisory, administrative, financial and other material assistance in order to improve the housing circumstances of their employees" (DOH [10]). In the White Paper (DOH [10]) the government makes provision for financial assistance for housing South African residents in the form of subsidy assistance. In the case of the mining industry this subsidy assistance does not play such an important role due to the average income of mine employees being higher than the minimum requirement of R3 500 (\$467). Most mine employees therefore further faces an affordability constraint due the absence of assistance from government.

A more recent and informal approach to housing mine employees is the socalled "Open Townships" policy. This concept indicates through its principles that mining companies should facilitate affordable housing for its employees; encourage home-ownership amongst employees; develop viable and sustainable housing in relatively close proximity to the operations; and to integrate employees into the nearby town/s without forming a mine village. The open townships concept reiterates what most of the other discussed policy guidelines state.

Lastly, another private sector initiative is the Social Contract for Rapid Housing Delivery (SCRHD) (DME [11]), which was signed by various stakeholders, including the Chamber of Mines. In terms of the SCRHD, the mining industry has committed itself to promote the sustainable development approach of the Mining Charter [8] including support for local entrepreneurs involved in housing and promoting home ownership and other forms of tenure for all employees. The mining industry indicated that they would interact at mine and/or regional level on an ongoing basis with local and district municipalities to ensure that there is an alignment and integration in development of towns and housing units.

It is evident that a void exists in terms of national policy guidance with regards to accommodating mine employees and enabling them to invest in a sustainable viable community in proximity to their place of employment.

\section{Towards a sustainable habitat}

One can't argue past the fact that the indirect responsibility of housing provision for mine employees falls solely on the shoulders of mining companies who in the past provided accommodation in an unsustainable manner within isolated and enclosed settlements away from established sustainable urban settlements.

Even though it is most of the mining companies' aspiration to move out of the housing business, some of them recognise their social responsibility and obligation to their employees. It is proposed that mining companies should, therefore, be (i) willing to play a facilitating role for an interim period to assist 
their current and future employees in obtaining security of tenure. Employees should be (ii) empowered to make provision for their own housing, and in this process of empowerment the mining company should play a central role.

As previously discussed, housing forms an integral part of the larger urban system and therefore housing development must be (iii) done in co-ordination with infrastructure and social development. Mining companies should (iv) take into account the various national policies and legislation, provincial development policy, and municipal policy and legislation as mentioned in this paper. In South Africa most of the Municipalities do not have the capacity to facilitate these processes and the mining company accordingly, has an indirect responsibility to (v) safeguard property value for employees. The mining company is consequently indirectly responsible for (vi) coordinating and securing social amenities for employees, i.e. private schools.

Although most mining companies have indicated that housing provision is not their core business, numerous indirect options and policies can be designed so as to take the emphasis away from the mining company, but still provide benefits to the employees. These indirect options include (vii) transport facilitation, (viii) travel allowances etc. to be integrated in a transport policy, as well as (ix) financial facilitation by means of a financial policy for acquiring housing in a sustainable settlement. It should be the vision of the mining company to (x) play a facilitating role in the process of land, service and housing acquisition and provision. It should further be envisioned to (xi) integrate employees within the urban fabric of surrounding urban settlements i.e. to discourage an isolated mining village within these nodes. The mining company's approach to housing and service provision should be (xii) to create options that will allow employees to implement sensible and affordable choices with regard to accommodation.

Mining companies should approach this growing dilemma from a strategic point of view by scientifically (xiii) accessing information on the availability of land, the long term sustainability of surrounding settlements, the availability of the necessary engineering services, as well as the affordability of and investment value for employees. It is proposed that mining companies consequently attempt to (xiv) establish a housing policy as a guiding document to state their viewpoint and approach to housing. It should be the specific aim of each mining company to, through this policy document, (xv) redress historical social and economical inequalities and (xvi) promote equitable access to land and housing for all employees. Mining companies should further strive to play a facilitating role with regard to housing (for a transitional period only.) by (xvii) establishing a vehicle to accommodate housing matters. It is also the responsibility of the mining company to (xviii) expand the financial skills and knowledge base of employees with regard to housing matters by means of education, training and development.

It is further envisage that mining companies should (xix) play a larger role in encouraging sustainable settlement choice through qualified regional analysis techniques. Mining companies should especially (xx) promote private homeownership and security of tenure of employees. Through its position as major employer in a developing country, the mining company should assist in 
providing a number of choices and options for employees with regard to housing. In contrast to past and present practices it is emphasised that (xxi) the development of family units and housing for the employees should be encouraged in order to provide a socially sustainable and responsible environment. Lastly, through its endeavours to better the lives of employees it is the responsibility of the employer to (xxii) discourage the materialisation of informal and unsustainable settlements.

This proposed mind-set will in the medium term, contribute towards the UN's double-barrelled purpose [2] of "adequate shelter for all" and "sustainable human settlement development". This approach further envisages the UN's stance that "economic development, social development and environmental protection should act as interdependent and mutually reinforcing components of sustainable development which can be realised through solidarity and cooperation within and between countries and through effective partnerships at all levels" [2]. This refers to the cooperation and partnership that should be established between national Government and the local private mining sector.

The suggested approach will further contribute to the South African Government's own vision [10] of establishing "viable, socially and economically integrated communities, situated in areas allowing convenient access to economic opportunities as well as health, educational and social amenities". The discussed principles will aid in providing habitable, stable and sustainable public and private residential environments for viable households and communities, as envisioned by the Government.

It is required that players in the global market, such as mining companies, must adhere to global and local policy directives. Therefore, as the second largest housing provider, the mining sector must contribute towards the urban fabric and economy in South Africa through a sustainable and socially responsible development approach towards housing. It is recognised that there exist no single approach for solving the housing dilemma in the mining sector, but by combining and mobilising a diversity of resources, the abovementioned policy initiatives and innovative approaches the challenge can be met effectively.

\section{References}

[1] Bourne, L.S. The Geography of Housing. Edward Arnold: London, 1981.

[2] United Nations. United Nations Human Settlement Programme: The Habitat Agenda. http://www/unchs.org, 1996.

[3] Demissie, F. In the shadow of the gold mines: migrancy and mine housing in South Africa. Housing Studies, 13(4), pp. 445-469, 1998.

[4] Rex, J. The compound, reserves and urban location. South Africa labour bulletin, 1, pp. 4-17, 1974.

[5] O'Connor, A. The African City. Hutchinson \& Co: London, 1983.

[6] Crush, J. \& James, W. Depopulating the compounds: migrant labour and mine housing in South Africa. World Development, 19(4), pp. 301-316, 1991. 
[7] National Union of Mine Workers. A new housing policy and strategy for South Africa: Comments on the Department of Housing White Paper. Johannesburg, 1996.

[8] Department of Minerals and Energy. Mining Charter. Pretoria: Government Printer, 2002.

[9] South Africa. National Spatial Development Perspective. Pretoria: Government Printer, 2002 \& 2006.

[10] Department of Housing. White Paper: a new housing policy and strategy for South Africa. Pretoria: Government Printer, 1994.

[11] Department of Minerals and Energy. Social contract for rapid housing delivery. Pretoria: Government Printer, 2005. 